\title{
No Obvious Home: the Public's Dialogical Creation of Home During the Third Wave of Decolonization
}

\author{
Kesi Mahendran $^{1}$ (D) Anthony English ${ }^{1}$ (D) . Sue Nieland ${ }^{1}$ (DD \\ Received: 29 July 2020 / Revised: 2 December 2020 / Accepted: 5 December 2020 / \\ Published online: 13 February 2021 \\ (c) The Author(s), under exclusive licence to Springer Nature Switzerland AG part of Springer Nature 2021
}

\begin{abstract}
The global crises we currently face, ecological, refugee-related and dealing with austerity arising out of the Covid-19 pandemic share a common feature. Together they have the capacity to call into question shared understandings of what constitutes the physical, political and psychological boundaries of home. Consensual understanding (social representations) of home, if unexamined, risks retaining primordial, stable, bounded and historically continuous dimensions. The focus of this article, to this end, is the public's understanding of home. The "un-homing" techniques used by populist leaders are brought into dialogue with how citizens, as dialogical selves, talk about home. The contours of common-sense on belonging are being informed; it is proposed by a third wave of decolonization. Stimulus-led interviews $(N=76)$ were conducted in England, Germany, Ireland, Scotland and Sweden. Dialogical analysis shows the public use two social representations relating to (i) freedom of movement and (ii) how the world is organized. These social representations decolonize home beyond national/transnational boundaries towards the transglobal. Citizens, irrespective of degree of migration, navigate future (in) securities using intergenerational dialogue. This serves to anchor transglobal migration-mobility to intergenerational continuity and the possibilities of travelling together through life. Public dialogue, when diffracted into a spectrum of positions on home, has the capacity to counter black/white, us/them, xenophobic protectionism within nationalist populism. In conclusion, scientific studies which reveal the depths of public capacity may become centrally important to post-pandemic recovery.
\end{abstract}

Keywords Dialogical self · Social representations · Migration · Public dialogue · Decolonization · Home

\section{Introduction}

"[V]iciously telling the United States, the greatest and most powerful nation on Earth, how our government should be run. Why don't they go back and help fix the totally broke crime infested places from which they came" US President, Donald Trump, 14 July 2019, Twitter.

Kesi Mahendran

kesi.mahendran@open.ac.uk

1 School of Psychology, The Open University, Milton Keynes, UK 
"I believe...my children at the moment (.)they won't decide to go and settle back in Sudan. This is their place, and this is how they feel they were brought here, and that's their home. They love to go to Sudan, visit the grandparents and the aunties and other things, but like a holiday. They are not thinking about work or to study there". Kazima Badawi, ${ }^{1}$ MMC7, London.

Kazima Badawi's use of "go and settle back in Sudan" provides an unsettling counter narrative to the black/white us/them binaries of US President Trump's use of "go back." Trump's now familiar nativist tropes of "our nation," "our government" combined with "go back" serve to deny co-eval status. They "un-home" four congresswomen Ayanna Pressley, Ilhan Omar, Alexandria Ocasio-Cortez and Rashida Tlaib and frame them as out of place. This article examines how the success of Trumpism and other on-going populist political projects rely on unexamined social psychological assumptions about the relationship between home, racialized logics and migration-mobility. These assumptions have chronotopic (timespace) qualities in so far as they reach back into an imagined past, to propose glorious futures whilst simultaneously setting boundaries about who belongs in the national space. Nationalist populism succeeds by creating a sense of a threatened present and an imagined encroachment on the "true people" by those designated Other into the home space.

Kazima's construction of home, in contrast, relies on two central dialogues: a transnational dialogue between London and Sudan and an intergenerational dialogue between a mother and her children. This article elaborates both of these dialogues drawing on a cross-European empirical study where citizens, such as Kazima, evoke the home concept as an analytical category when asked questions on integration and citizenship. The dialogical analysis presented below, using a migration-mobility continuum (Mahendran, 2017; Mahendran, 2018), reveals how the public's own processes of homemaking potentially diffracts the black and white binaries of populist thinking into a spectrum of dialogical positions on home.

The relationship between conceptions of home, and degree of migration-mobility, sits at the intersection of four interrelated global crises, the refugee-crisis, austerity, climate crisis and the Covid-19 crisis. These global crises, and the flat timespace global communications platforms that facilitate them, enable politicians today to publicly call into question the boundaries of home and who gets to belong. The Covid-19 pandemic has foregrounded the centrality of home, whilst curtailing freedom of movement particularly cross-border movement. Raising the question of how the intra-action between migration-mobility and home may be mobilized by populist politicians during post-pandemic recovery which is likely to be characterized by high levels of austerity.

The last decade, in parallel to these crises, heralds a growing global disquiet about persistence of racialized logics and white imperial consciousness which has found its expression in Black Lives Matter. Such movements respond to the aforementioned entrenched psychological indexed "un-homing" of black and brown skinned people as out of place and valorising of white neoliberal selfhood (Abreu 2020; Bhatia 2002; Bhatia \& Priya, 2018). As articulated further below we understand these developments as a third wave of decolonization.

\footnotetext{
1 All names have been anonymized but retain cultural distinctiveness; names are followed by position on the migration-mobility continuum (MMC, Mahendran, 2017) and city of interview.
} 
"EU migrants have been able to treat the UK as if it's part of their own country for too long" UK Prime Minister Boris Johnson, 8 December 2019, The Times.

"I think my (.) my belonging is almost. I feel like I belong to a sort of divided family group as well because my partner's German, so we have a transglobal issue (...) with our families and our histories. I guess I identify with a lot of people in that I know it's an increasing number of people that have no obvious home". Billie Vogel, MMC8, Glasgow.

It is likely that post-pandemic recovery will create increasing tensions between the hardening of national borders, as displayed by UK Prime Minister Boris Johnson ahead of the last national election, and the realities of how citizens themselves traverse borders in order to establish a sense of home. Billie Vogel rhetorically locates her own story amongst "a lot of people" to explain her sense of home involving a transglobal chronotope which combines families (intergenerational) with histories (continuities). She proposes that citizens whose sense of home crosses national boundaries are no longer a minority "an increasing number of people have no obvious home".

Yet, her subtle use of obvious brings Billie's account of home into dialogue with an unstated yet hegemonic social representation of home. The Covid-19 pandemic crisis (henceforth the pandemic) and the ecological crisis reveal the extent to which nationstate borders can be crossed. The privileging of secure borders during the pandemic raises questions about how populist projects may well restrict freedom of movement across the globe during post-pandemic recovery.

Populism mobilizes along two Manichean binaries; a vertical-ordinary people versus corrupt elite — binary and a horizontal — true people versus the Other-binary, pointing to the importance of conceptualizations of the people. Studies investigating this have tended to focus on the dynamics of intergroup conflict and antagonistic reasoning (Spruyt, Keppens, \& Van Droogenbroeck 2016; for review see Obradović, Power \& Scheely-Skeffington 2020). These survey-led studies reveal the psychological processes which support boundary-making amongst individuals. Such cognitive accounts sustain thin conceptions of people. They rarely offer thick subjective and intersubjective accounts of "the people" acting in a public capacity.

Understanding how the public, acting as dialogical citizens "in a public capacity" (Dewey 1927/1954; Mahendran, 2018) understands them as having what Hannah Arendt conceived of as an "enlarged mentality" (Arendt, 1961). She states "this enlarged way of thinking, ... needs the presence of others 'in whose place' it must think, whose perspective it must take into consideration and without whom it never has the opportunity to operate at all" (p. 21). Both Dewey and Arendt believed in the imperatives of the public to think as a public. For Dewey if "the consequences of the conversation extend beyond the two directly concerned, that they affect the welfare of many others, the act acquires a public capacity" (Dewey, 1927/1954, p. 13). To facilitate this, the design of the study presented below, brought citizens into dialogue with European Union policy statements on integration and citizenship.

The remainder of the review involves three steps; it first draws together existing literature on the (in)securities of home, drawing from sociological and political science. Second it then relates home to migration-mobility by exploring the parameters of the European Union's freedom of movement principle. The final step unpicks how populist leaders promote conflictual us/them worldviews within the populist chronotope (timespace) of a threatened present. 
The success of populist projects in "un-homing" and positioning some citizens as "out of place" is heavily reliant on an unexamined common sense circulating at speed via mechanisms of direct democracy (e.g. Twitter). We combine DST-Dialogical Self Theory which foregrounds the plasticity of the dialogical self as comprising a number of I-positions (Bakhtin, 1975; Marková 2003; Zittoun 2014; Hermans \& Dimaggio 2007; Kinnvall \& Lindén 2010; Nesbitt-Larking 2008) with SRT-Social Representations Theory (Moscovici 1984; Marková, 2003; Staerklé \& Green 2018) to imbricate these I-positions within the constraints and opportunities of common-sense (consensual reality).

\section{Home as Self-stabilizing}

The cross-European study presented below focused on questions of integration and citizenship. No interview questions were asked on the concept of home and yet, when discussing integration, citizens employed various often ambivalent and insecure accounts of homemaking-irrespective of their degree of migration-mobility. This suggests the importance of home as an analytic category which plays a stabilising anchoring role when talking about integration. Intriguingly, this anchoring of home did not seem to involve cognitive closures to anchor home to familiar representational knowledge (a central tenet of social representations theory). Instead, it produced unfinalized openings which moved through space and time and are diffracted here into a spectrum of positions.

Studies into processes of homemaking increasingly depart from home as a placedbased concept relating to roots and reterritorialize home as relating to routes and diasporic transnational relations in space (Ahmed, Castañeda, Fortier \& Sheller 2003; Murrani 2020). For Murrani this is a question of cognitive/neuro plasticity which makes humans capable of constantly conceptualising home, not as a reaction to outside forces/stimuli but as an active agency within a radical creative space. Murrani's theorizing on the creative potential of an edgeless conception of home contrast with the sharp-edged nation-state conception of home, articulated by leaders such as Donald Trump (USA) or Boris Johnson (UK).

References to "homeland," "home affairs," "homefront," "home office" and even the ever present "home" tab sitting in the corner of digital screens serve to semiotically mediate the ontological dimensions of home as bounded and security-related. Political scientists addressing the mobilization of ontological insecurity show how political projects make use of the primordial and "the self-stabilizing qualities of home" (Mitzen, 2018, p.1376) albeit sometimes implicitly. Though we may instantly recognize home to be the site of constraint and threat (e.g. gender-based violence), politically home is presented as the site of routines, a private refuge, a place to escape from an uncertain world. This conception of home is significant because it often opaquely frames sense-making of international relations (Mitzen, 2018).

Is it possible then to articulate a conception of home beyond this ontological security? Fortier follows queer migrations as anti-normative stories of leaving and returning home. She articulates a queer diaspora, where, being required to leave the family/birthplace home in order to be oneself, initiates a state of being outside home, nation-state and "homeland". This exiled status then comes home in new spaces of assembly (Fortier, 2001). This coming home, as destination rather than starting point, offers considerable transformatory epistemic potential. It retains the ontological politics of recognition, familiarity and attachment combining this with the affective dimension of feeling at home. Fortier is careful not to site these homes-spaces as urbanized queer cultural homelands, but rather 


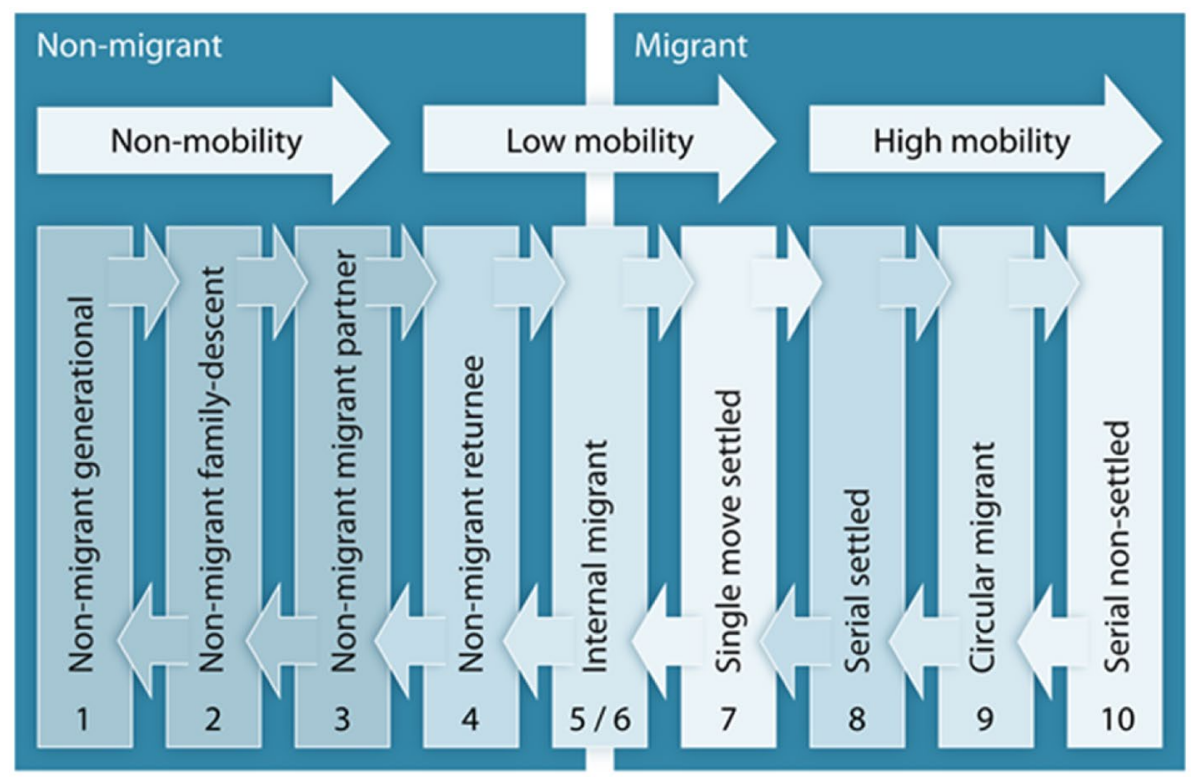

Fig. 110 position migration-mobility continuum (Mahendran, 2017; Mahendran, 2018)

following Hall proposes "points of suture" (Hall 1990, p.226). Home becomes spaces to engage in connections whether cafés, bars, collective events or holiday destinations. Equally on-going return visits to the family home allow people to reflexively pick and unpick these sutures of homemaking, belonging and identity practices.

The experience of home as moving through time and space is central to our analysis. Citizens articulate home-as-attachment, anchoring home to past and future spaces. This leads us to follow Bakhtin in using a chronotopic approach (Bakhtin, 1975). Psychological accounts of homemaking therefore may be better understood as a transitive verb (Simão 2007 ) besides the noun of home as site/space/sense. Home is navigated by moving between different I-positions of a dialogical self (Bhatia 2002; Marková 2003; Zittoun 2014; Hermans \& Dimaggio, 2007; Kinnvall \& Lindén 2010; Nesbitt-Larking 2008) where differing positions promote multiple I-Other dialogues (Simão, 2007).

\section{Decolonizing Home via a Migration-Mobility Continuum}

Understanding home as transitive practice, involving past, present and future, immediately suggest the role of movement in homemaking. We refer to movement both in the sense of the imaginative leaps that allow us to take an other's position-dialogical movement, (Zittoun, 2014) and also in terms of migration-mobility movements. Citizens are understood as having different degrees of migration-mobility (Mahendran, 2017; Mahendran, 2018), from position 1, generational non-mobility to position 10 serial migration where citizens fully imagine they will move again (see Fig. 1). Beyond this there are social transnational moves pivotal to EU freedom of movement, from working briefly in another memberstate, to short holidays, to visits to see friends and family as a part of "Everyday Europe" (Recchie, Favell, Apaydin, Barbulescu, Braun, Ciornei, et al 2019). There are two risks here; 
the first is in overplaying capacity to move. Returning to questions of decolonization, white citizens have a much greater capacity to move than others (Sheller \& Urry 2006; Sheller 2017) and whilst new cartographies are being developed to explain freedom of movement in Europe, these are stubbornly stratified by socio-economic status (Savage, Cunningham, Reimer and Favell 2019). As the analysis will show below, these factors influence social representations (common-sense shared knowledge) of freedom of movement and how the world is organized.

Alternative social representations of how the world is organized have the potential to widen our horizons and narrative imagination beyond a Euro-centric Manichean ordering of the world into compartments, Black, White, Arab and Christian countries (Fanon, 1961/2001, p.115). Fanon envisions a world where we have shaken off the settler's logic, beyond a desire for national liberation as a game of catch-up, towards a true decolonization of consciousness. He proposed a post-imperial inventive consciousness with "the Third World starting a new history of man" (Fanon, ibid. p.254).

Populist black/white us/them "un-homing" practices (and their potential for diffraction) can be understood as occurring within the socio-political context of a third wave of decolonization. The first wave led to the independence of former European colonies in the 1940s and 1950s - the very independence that Fanon was seeking to look beyond. The second wave led to desegregation and rising black political consciousness in the 1960s. It is worth bringing to mind the Black Power movement which became worldwide in its political and cultural influence (Hall, 2017, p.99). As noted above, the pandemic and ecological global crises have been partly influenced by flat timespace global communications and related global consciousness.

The third wave, we propose, can be located after the post-racial discussions of the Obama US presidency and Blair/Brown centre-left UK government, but before the Covid19 pandemic. Where the first wave was about emerging independent nation states and the second about desegregation, this third wave benefits from a transglobal chronotope and sets its sights on a post-imperial consciousness. Rhodes Must Fall and why is my curriculum white campaigns, the Windrush scandal in the UK, \#JusticePourAdama in France and the global lightning rod of the death of George Floyd lead to widespread global dialogue and political movements creating this third wave. The third wave of decolonization challenges the assumptions of European cosmopolitanism which support ideals around freedom of movement within the European Union project. It exposes the EU's neo-imperialist Eurocentric assumptions. Decolonization involves reframing the very narrative of the EU project as the coming together of European colonial powers, rather than war-ravaged nation-states engaged in a supranational peace project (Bhambra \& Narayan, 2017).

\section{The Threatened Present: How Populist Political Leaders “Un-home”}

To sum up, multiple I-positions within the dialogical self enables homemaking to be understood as a dynamic process travelling through time and space. I-positionality, though highly plastic, is restricted by populist leaders mobilizing black/white us/them accounts of who belongs and who is "out of place." This rests on social representations about the relationship between belonging and migration-mobility. As demonstrated in the analysis key representations are pivotal-freedom of movement and representations of how the world is organized. Diffracting these representations potentially shifts the horizons of 
figure-ground beyond the European Union project and its unexamined neo-colonial imperial logic, towards decolonization and post-imperial consciousness.

The opening tweet from Donald Trump and the statement by Boris Johnson point to how citizens can be positioned as over-stayers ("for too long") to temporalize citizenship status. This foregrounds the extent to which populist chronotopes rely on a threatened present. Not only does this create insecurities for citizens (at the point of moving), now re-cast as migrant (in the UK Brexit scenario), it also creates future-insecurity in those who have not moved.

These tactics occur across Europe, where some political projects make explicit use of the home concept. Within the Swedish context the long-standing explicit use of Folkhemmet (people's home) has become re-mobilized by the populist Sverige Demokraterna/Sweden Democrats political party (SD). In Sweden folkhemmet is nostalgically associated with the guaranteed securities of a golden age of social democracy. Its use by SD involves an over-sharp distinction between welfare chauvinism between natives (contributors) and immigrants (non-contributors). Folkhemmet becomes something available only to "real Swedes" (Mahendran, English \& Nieland, 2021; Hellstrom \& Nilsson, 2010; Rose, 2017). The extent to which Sverige Demokraterna, once understood as a Far-Right party, has become integrated into a reasonable mainstream can be seen across Europe. In each instance fears about home are hyper-generalized.

In Tateo's analysis these hyper-generalized sign fields builds an atmos-fear of threat, fear and insecurity which succeeds in framing everything else (Tateo, 2019). Tateo shows how war rhetoric as a semiotic field increases fear-based patriotism rather than responsibility (Tateo, 2019). Home, with its affective nature which is not always easy to put into words, exists as a higher semiotic affective field, beyond cognitive or discursive categories, or labelled emotional terms such as "happy" or "sad." Indeed, many of the vulnerabilities and insecurities of home relate to the extent to which home-making involves reaching forward into the unknown and reaching into space that is foreshadowed.

The use of war rhetoric to create foreshadowing is central to pandemic-related crisistalk by populist leaders. This echoes the war rhetoric already in use when talking about getting tough on immigration to protect the homeland (Mols \& Jetten, 2014). The threatened present chronotope uses threat not as an opportunistic capitalising on exogenous events (e.g. the pandemic) rather leaders "go to great lengths to cultivate threat perceptions" (Mols \& Jetten 2014, p.84). Such threat perceptions can then find an audience with susceptible publics (Staerklé \& Green, 2018) who respond with antagonistic/conflictual thinking (Spruyt et al, 2016; Obradović, Power \& Scheely-Skeffington, 2020) and hyperpartisanship (Singh, 2017). Hyper-partisanship is central to both vertical forms of populism of "corrupt elites" versus the people and horizontal forms of populism of the "true people" versus the Outsiders as Others (Mahendran, English \& Nieland, 2021; Mudde, 2019). This raises the crucial methodological question - what conditions reduces hyper-partisanship so citizens feel sufficiently secure to reveal the ambivalence features of their ongoing homemaking.

\section{The Present Study}

The Placing Ourselves study, a cross-European collaborative project, was designed to bring citizens into dialogue with the parameters of freedom of movement. Such supranational freedom of movement-an aspiration since the conception of the European Union project within the Treaty of Rome in 1957)—became formally ratified within the Maastricht 
Treaty in 1991. The sites selected include those in Schengen (Germany and Sweden) and those outside it (UK and Ireland). Face-to-face interviews were conducted in Glasgow and Gothenburg by the lead author and two research assistants. In Dublin, Düsseldorf and London by project collaborators.

The dialogical design involved stimulus-materials consisting of existing EU policy statements and images taken from the Hague programme (Council of the European Union, 2004) and the Common Principles for Integration (Council of the European Union, 2004; Mahendran, 2021). The point of the departure of the interview was open-ended stem completion "How would you complete the sentence - I am a part of?" This became progressively more dialogical, as participants were presented with the policy stimulus materials.

\section{Participants}

Adverts in local adult-education colleges in each city facilitated chain sampling from the initial responders. The sampling frame used a quota sample along the 10-positions of the Migration-Mobility Continuum (Mahendran, 2017; Mahendran, 2018). Though the study involved an equal number of migrants and non-migrants using the MMC, as outlined above, allowed us to move beyond two key binaries migrant/non-migrant and public/ migrant. The MMC is measured by participants responding to six questions mapping their degree of mobility and settlement onto 10 positions (see Fig. 1). Naturally, participants can speak, as discussed, from a variety of positions; however, biographically, this allows us to analyse migration-mobility as continuous, from generational non-mobility (position 1), to short periods working abroad, to serial movers who plan to move again (position 10).

Age ranged from 18 to 74 with an equal number of men and women. Participants had varying degrees of educational backgrounds and various occupations including professional people, semiskilled, unskilled and people who were unemployed. Participants revealed key demographic details e.g. ethnic identifications and relationship status, and these are shown in the extracts where relevant. Semi-structured digitally recorded interviews were carried out in 2012/2013 ( $N=76$ ). Ranging from 45 to 128 min (mean=88 min). Interviews in Dublin, Düsseldorf, Glasgow and London were conducted in English, and in Gothenburg in English and Swedish. Swedish interviews were translated into English, and all analysis was conducted in English. ${ }^{2}$

\section{Analytical Procedure}

Interviews were imported into NVivo 12 and explored via four search terms-home, house, village and town. Because the study was designed at city level, we did not include the search term "city." Home on its own revealed 378 references within 71 out of the 76 interviews which enabled sufficient depth to conduct a dialogical-social representational analysis.

Dialogical analysis was conducted in three stages, first separately by each author then through co-analysis sessions using on-line Skype meetings. In the first stage all references to "home" were reviewed to identify (i) the key internal and external I-positions being used e.g. I-parent, $I$-child etc. and (ii) the multi-voicedness by authoring the voice of another

\footnotetext{
${ }^{2}$ Interviews were carried in some cities by collaborators as follows in Dusseldorf interviews were carried out by Dr Nicola Magnusson, in Dublin by Dr Ima Jackson, in Glasgow by Dr Rebecca Rotter and the first author, in Gothenburg by Dr Helen Arvidsson and the first author and finally in London by Anubhuti Kapoor working with Dr Caroline Howarth. The authors would like to express thanks to all participants who gave their time and to fellow collaborators on the Placing Ourselves project.
} 
and how these related to MMC position. In the second stage, in order to facilitate the social representational analysis, we looked at (i) how home was bounded with terms such as us/we/they (Mahendran, 2018), (ii) the chronotopes used (timespace) temporal-spatial features in particular e.g. open/closed and past/present/future (Marková, 2000, Mahendran, 2018) and (iii) what common-sense knowledge is being assumed between interviewer and interviewee.

In the final stage we returned to the full transcript of eight selected interviews and re-contextualized references to home. This process led to two key dimensionstransnational and intergenerational dialogue. These were then further understood as relating to chronotope (see Table 2) and that transversal or traversal aspects of homemaking related less to the transnational and more to transglobal.

\section{Analysis: Two Dimensions to Public Dialogue on Home}

Our analysis is organized around two key dimensions to homemaking-transglobal and intergenerational dialogue. Intergenerational dialogue is deeply inter-related with transglobal dialogue - however, these are presented separately to draw out key dimensions. Intergenerational dialogue serves to anchor the more unfinalized transglobal dimensions (see Table 1).

\section{From National, through Transnational to Transglobal}

Citizens use national terms such as Sudan and Germany to communicate within a shared representation which articulates the world as consisting of a world of nations. When discussing home, citizens move beyond these terms to articulate often highly affective transglobal worldviews. As noted, citizens engage in transnational/transglobal dialogue across different degrees of migration-mobility (mapped as MMC position number see Fig. 1). The following extracts focus more closely on how these boundaries around the world are drawn from global relations, to going beyond this world (see first column Table 1). Within Extract 1, Hala dialogically moves between a one world position ("no barriers") total freedom of movement, idealized imagined $I$-mobile citizen to an I-outsider position in relation to the western world. In his social representation of the world, he delineates between the west but leaves open what is beyond the western world.

\section{Extract 1: Not everyone feels comfortable in the Western world.}

Hala: Dual citizenship. (8) Well maybe it's the closest to the best (Laughs) I think the best is no barriers. (Int:: Okay, yeah, yeah). Yeah. Er (3) It's not (.) it's not impossible. It really is not impossible. You know why? Because it's been like that before (.) not so long=

Int (First author): = But people might say (.) you know (.) the world is much more populated now, everybody would want to go to the rich countries.

Hala: It's not really true. It's not really true. People would want to go where they feel comfortable. They would want to go where they belong (.) you know (.) a:nd not everybody feels comfortable here for instance, in the western world. 


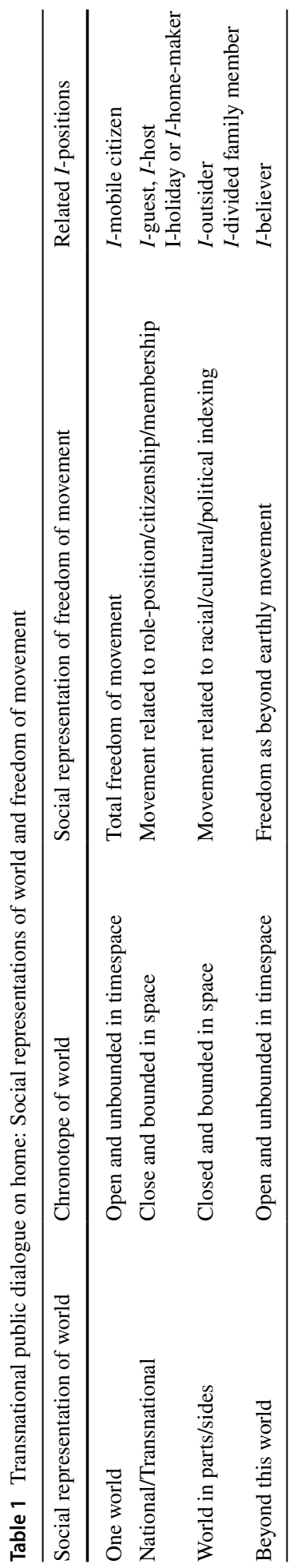


Table 2 Intergenerational public dialogue on home: Related anchoring chronotopes

\begin{tabular}{ll}
\hline -positional dialogue & Anchoring chronotope \\
\hline $\begin{array}{l}\text { Grandmother/Mother/Daughter/Mother- } I \text {-positional } \\
\text { dialogue }\end{array}$ & $\begin{array}{l}\text { Past/Present grounding to create historical conti- } \\
\text { nuities and future-security }\end{array}$ \\
$\begin{array}{l}\text { Parent/Children } I \text {-positional dialogue } \\
\text { Wife/Husband } I \text {-positional dialogue }\end{array}$ & $\begin{array}{l}\text { Moving together through spacetime } \\
\text { Representing the future as closed to anchor the } \\
\text { present }\end{array}$ \\
\hline
\end{tabular}

Not everybody feels comfortable who has moved away from (.) from where they (.) you know they call home (.) you know. Probably they've (.) they've left (.) you know that, to continue to live, but it doesn't mean that they feel totally comfortable.

(...).

Int: Would you put yourself under that flag there ${ }^{3}$ ? Do you think of yourself as a European citizen?

Hala: (4) At the moment not as much as I would like to because I can't just wake up today and say I'm going to er (.) er (.) France without any entrances. I'll have to go through an immigration process (.) you know (.) which I hate doing you know. I really hate it. Maybe because of the Ghana experience. Hala Warteng, MMC7, Glasgow.

When Hala discusses the Ghana experience, he refers to the complicated process of visiting Ghana from the UK and the visa requirements given his leave to remain status in the UK. His sense of constrained migration-mobility contrasts with Extract 2 Qovena Blerta, a white European who articulates a sense of freedom of movement.

\section{Extract 2: You can settle any place in the world.}

Int: Okay. Alright, the last question on these (.) um (.) sort of personal topics is whether you're settled in Glasgow, or do you imagine that you might move again? And if you did move, why would you move?

Qovena Blerta: E::r (.) I (.) yeah, ${ }^{4}$ this is actually a very personal* and tricky question (2) I love life I'm living just now and my commitments and engagements here as well. Only reason I would move if my children moving and I would be with them. I would like to be with them but it's not (.) er (.) necessary because I left my Mum behind because $\mathrm{I}<$ had $>$ to. But this is actually good now as a British citizen, you can travel and you (.) you can settle any place in the world and you don't need, you know, to go through all procedure of applying for settlement. You can go back to Kosova or another country and this is actually is only reason I like to be nearby my children, where they are, but that (.) er (.) I have three sons and you never know where they are, they can be in three different part of the (.) er (.) world and maybe I

\footnotetext{
${ }^{3}$ Participant is shown an image of planet earth being held up by hands with different colour skins, from white through brown to black. At the top of the planet, a European Union flag has been placed into the planet.

${ }^{4}$ Following Jefferson conventions, *denote laughing when talking* (.) short pause, (4) 4 second pause and (...) text removed. 
(.) I have to travel just to (.) to (.) not stay with them but to be nearby. (QB, MMC7, Glasgow).

Qovena's I-British citizen position provides freedom of movement to settle, she believes, anywhere in the world. Qovena (MMC7) illustrates the unfinalizable dimension of settlement and transnational horizons of the freedom to move around the world to be near relatives. Equally Qovena illustrates how dialogical positioning maintains tensegrity (Marsico \& Tateo, 2017) by carefully balancing a narrative of the losses, of seeking refuge from the Kosovan war, having to leave her mother, to the gains-loving life now and having British citizenship. Qovena moves between a social representation of the world as transnational to one of the world as parts as her horizons widen when imagining where her three sons might live. In this chronotope the world and the future are wide open, but ultimately bounded by nation-state citizenship (see Table 2).

Qovena and Hala are both MMC7 (single move-settled), yet their representation of freedom of movement is quite different. Retuning to Billie Vogel (see introduction) here in the fuller extract she constructs home and belonging as relating to "both sides of the world." Billie (MMC8, i.e. serial mover settled) problematizes this ("a transglobal issue") as being more than logistics but also about histories.

\section{Extract 3: We can never cut ourselves off from one side of the world.}

Billie Vogel: I think my (.) my belonging is almost (.) I feel (.) I feel like I belong to a sort of divided family group as well because my partner's German so we have a transglobal issue * with um* (.) with our families and our (.) our histories. I guess I identify with a lot of people in that I know it's an increasing number of people that (.) that have no obvious home that they will go back to with their family. (...) So we're always going to have family on both sides of the world. So we're never going to really feel like we're (.) um (1) we're in one place forever because (1) we can never (.) we can never just cut ourselves off from one side of the world (Billie Vogel, MMC8, Glasgow).

Born in Australia, Billie uses an important dialogical and rhetorical move, placing herself into a transglobal group of an "increasing number of people" who have "no obvious home." She articulates the plasticity and relational agency of a dialogically engaged self outlined in the introduction (Marková 2003; Zittoun, 2014). However, equally, she illustrates the limits of a dialogical self; this is not yet an emancipatory counter social representation to home as birthplace (Mahendran, English \& Nieland, 2021). There is a sense of this social representation being a shared yet subordinated representation. Positioning herself amongst an increasingly common group anchors her sufficiently to engage in a series of spatial moves, "back to family" and forward to an unknown wide horizon. "Never" does not land in a neverland but rather retains an affective dimension, "we're never going to really feel/we can never." Though Billie presents herself as a member of a highly global group, this group inevitably has intimate relations with more rooted family members. In this social representation the world is also divided but this time into sides-the dialogical self, navigating the tensions created by these sides as I-divided family member (see Table 2).

It could be tempting to conclude that a transglobal homemaking is the preserve of those in the higher positions on the Migration-Mobility Continuum. Our findings suggest it relates as much to generational non-mobility/low migration-mobility. In Extract 4, Olivia Newington is quite clear that she would never move from England, 
because she has not been called (by God) to do so-an I-believer position. Olivia says "Yes, absolutely" to the question of belonging to London but later when talking about recent events in London she dialogically switches from this seemingly certain I-believer position towards a higher more abstracted reasoning.

\section{Extract 4: Not of this world.}

Int: Have you ever moved away and moved back to the city?

Olivia: Nope, I was born in the suburb and now I live in the city. I mean I've had holidays in wonderful (.) not abroad, only in the UK, but (.) to some lovely places.

Int: Have you ever planned to leave your home country?

ON: Nope (Int: Why not?) Because uhh (.) I've never felt, you know, called to do it.

When I was in my late teens, I remember praying to God, that I would not be called to be a missionary, because I didn't want to go abroad (laughs), and then I had to do some missionary job here in England after all.

(...).

Int: Have these events (Is referring to events in London, she talks about terrorist attacks) or others that have happened over the past years, affected your sense of belonging?

Olivia: (2) I don't think so. That (6) we, we have a phrase, 'being (1) in the world but not of the world' in the religious sense you belong to God, and you belong to everybody, because we're all part of God's creation. And everybody is needing that love and respect and so forth. Umm (2) but of course, you know, (1) in that sense I always feel I belong anywhere I go, but (3) at the same time, you know, I don't really belong. (laughs) Heaven is my home, whatever. Olivia Newington, MMC1, London.

Olivia leaves open the comment "I don't really belong" despite being born in England, whereas earlier she had been entirely unambiguous about belonging to London and being a citizen. She moves to a higher I-beyond this earth, higher abstracted reasoning.

\section{From "Going Back" to Intergenerational Continuity}

In addition to the transglobal processes by which citizens create a sense of home, this section explores how citizens use intergenerational continuity to anchor their sense of home into a past which can shape the horizons of the future (see Table 2).

\section{Guest/ Host}

Berrak Dalman sets up a dialogue with her mother and also with Istanbul. This organizes itself around a guest/host oppositional antinomy. Her response is multi-voiced in particular she creates a mother/daughter dialogue to explore the sense of being out of place (Extract 5). Her social representation of the world remains transnational and informed by an introjected nationalist Other who she is answering in this double-voiced dialogue.

Extract 5. A very modern life.

Berrak Dalman: Yes I think (2) erm my mum always said to me I have had such (1) a hard life that I will give my kids a very modern and comfortable life (2) we had a very hard life we don't have (2) water (2) we must carry our water and we must work from a very small age (3) and I said always to myself when I have some 
kids I will give them a very modern and free life so I am very free because she gave us a very free life (3) and I'm very lucky to have this life (3) but I know a lot of Turkish people with the life like my life so it's also usual very similar like me (.) Like, for example, (2) from the city Istanbul (.) those from Istanbul (.) most of them have very modern life (.) all of the people from village from the Turkish Village (2) they have a very hard life and a very religious life (.) that's a problem for Germany (...) yes it's different when you come from Turkey (.) I was born here (.) that's the problem it's not the same as when you come as a child because then you can feel like its home but when you come as an adult (2) to move to Germany I think you can't (2) stay here. It's too quiet here (2) when you come from Istanbul you don't have er (3) this Istanbul feeling here (.) so I think you feel like a guest. (Berrak Dalman, MMC2, Düsseldorf).

In the next extract, Berrak takes the voice of her husband to reveal the temporalities and continuities of a wife/husband dialogue by locating the story to the beginning of their relationship. This reveals how for some European citizens, born in Europe, there remains the on-going evaluative questioning of home-making about where to live to feel comfortable. Berrak brings the discussion to the lived present "but now" the need is gone. This could easily suggest an assimilation or accommodation within the cultural processes (Bhatia, 2002), but Berrak switches to a distinction between herself and husband- "for me" I never lived there, she sustains the $I$-holiday maker position in relation to Turkey-it is not her home.

\section{Extract 6 Good old Germany.}

Yeah in the beginning he said always I will move to Turkey back I will move to Turkey one day (.) but now he says no I don't need to move (3) so for me Turkey is for me holiday (.) it's a nice country but (.) I never lived there (1) I can't say to you oh I lived there and it was nice or it was bad (1) so I can't say to you if I could do it (3) I can try it but I don't know how (1) I know everything here (.) having an appointment with the doctor (.) going to the hospital (.) its different in Turkey (.) everything is different and (3) I don't know if I can do er if I could settle down (1) that's the problem (3) it's difficult to know so I don't think I will move I will stay here in $* *$ good old Germany** [*yeah*] **the hospital is very close the doctors are very close** I think it is ok. (Berrak Dalman, MMC2, Düsseldorf).

She anticipates a future within her lived present (Simão, 2007) and begins a process of managing that uncertainty of the time to come by saying "I don't know if I could settle down". Berrak ends with the laughing familiarity and comfortableness of "good old Germany," the familiarity of someone who is not a guest and Germany itself an intimate friend.

In Extract 7, Kazima Badawi who is settled in London responds to the question "are you settled or do you think you will move again?" There are similarities between her and Berrak but she goes further by introducing another generation, her children, opening up the horizons of the dialogue to imagine the future positions of her children. Kazima returns to the lived present and then employs an oppositional guest/host category. When Kazima reflects on whether England is her home, her positional moves relate to freedom/ responsibility dilemma- $I$-Free-Mover and $I$-Mother. Her use of the word "but" signals the affective tension expressed as repetition ("I feel, I feel") between moving on and staying in England. Kazima sustains this ambivalent citizenship by making a further 
identity move between I-English/I-Not English identities. Her daughter who "opens her eyes" in England is more English in thinking/culture. The articulation of her child as categorically distinct from "White English" introduces the racialized logic of the evaluative voice of the Other. White citizens are potentially the true people-the true English. The addressivities and dialogical nature of contested citizenship (often mobilized by populist leaders) is evident in the comment "I always have to mention." The multiple moves of the dialogical self within Extract 7 starkly reveals the extent to which intersubjective recognition involves an on-going negotiation for black and brown skinned citizens with the evaluation of others.

\section{Extract 7 My children won't settle in Sudan.}

Kazima Badawi: I believe (.) my children at the moment (.) they won't decide to go and settle back in Sudan. This is their place, and this is how they feel they were brought here, and that's their home. They love to go to Sudan, visit the grandparents and the aunties and other things, but like the holiday. They are not thinking about work or to study there. Our house, our home is here. I go and see my relatives frequently, now I'm not bound with children, little ones. So anytime I want to go I can, but I feel, I feel, this is how (.) I can't see myself away from my children, and uhh(3) this is we were (.) they were brought up, and this is where they wanted to stay (...) I'm English (laughs) I'm British, I've got British passport (.) I'm living in England, my home in England, but I always mention I'm not English, I have to mention my root. I have uhh... why I mention my root? Like my daughter might say different. My daughter will say that she is, like, brought up here, she is....although she is, like, not White English, but she is English in her culture and thinking. She can understand things like, more than me, because she opened her eyes in this country (Kazima Badawi, MMC7, London).

\section{Freedom to Move: Loyalties and Legacies}

Dilemmatic thinking and the use of intergenerational dialogue were found along the migration-mobility continuum. In Extract 8, Rachel Vacher who is in MMC1, i.e. a generational non-migrant, presents initially a hegemonic representation of home, referring to her son who lives in Germany as "coming home" to the UK where home relates to her son's birthplace. Projecting to a future self and the potential dependencies of old age, Rachel's intergenerational mother/son dialogue explores a future move. This become contingent on other relationships and the dialogue becomes multi-voiced, to create the Granny Rachel I-extended grandmother position. As before, Rachel, who is white, does not confront issues of recognition and contested citizenship, her account of the new sites of home reveals the extent to which freedom of movement within the European Union project is stratified by racialized logics. Though perhaps not as much by socio-economic status as suggested by Savage et al (2019) whose chief measure was operationalized as connections to another country.

\section{Extract 8: They call me Granny Rachel.}

Rachel Vacher: My son in Germany, they've bought a lovely house in Norwich. He's letting it out but he's (.) they're coming home in April and they want me to go and live with them. And I says 'well when I'm eighty, I'll come and live' but 
all my friends and my cousins, 'oh please' and wee [friend's name] 'Oh Rachel, no, you cannae go' coz wee [friend's child] calls me 'Granny Rachel' (.) eh (.) oh they would be broken-hearted if I went. But [my son], he wants me to go and live with him. But I love Scotland and I love my flat. But I don't know what like I'll be at eighty. I could also live in Denmark because I've got the families there. (Rachel Vacher, MMC1, Glasgow).

Rachel's sense of home reveals an intense affective love of place, in her use of "but". She works through the dilemma about her future home. Rachel demonstrates how social transnationalism has become every day for those who would be understood as non-migrants in survey studies (Recchie et al, 2019). This raises the questions of the changes in the sites and sense of home when the UK is potentially no longer part of the European Union's freedom of movement arrangements. It raises the critical question of how freedom of movement will be altered during post-pandemic recovery.

The final extract involves an adult child/older parents' dialogue. Extract 9 demonstrates the future affect that we engage as we try to use language to articulate something which is felt but which language (and by extension, existing social representations) has not yet encoded.

\section{Extract 9: I migrated to my wife.}

Int (First author): So, can I then ask you a kind of conceptual question (.) are belonging and integration different things?

Karl Axelsson: (12) yes I think so because belonging I belong to (2) I feel I belong to N-holm maybe my parents and (.) I still feel integrated here [mm] and I can if I think about other people they can belong to their home country they can have (.) because of war they move here they still belong to the thinking in their home country but they still can get integrated in Sweden.

Int: Would you say you belong to Gothenburg?

Karl: (5) no I:: I er (4) I:: migrated to my wife in Gothenburg (.) yeah I belong to N-holm I think (.) even if I dislike some of the things there too (.) but it was my home for almost 30 years so I (3) maybe I will belong to Gothenburg in the future yeah [yeah] but when I think about things (2) home is where er K-strand (.) and maybe when (1) when er (3) ok you don't think about those things but er when I think about when my parent isn't anymore I would er maybe I will lose the connection to N-holm (1) [mm] er it's maybe more about the connection to my parents and they live in N-holm (.) I don't know".

Karl offers a position on homemaking which diffracts the black/white binaries of un-homing practices of populist leaders and their accounts of who are "true people." Extract 9 does not have the imagined dialogues with projected others or the ambivalences of recognition and contested citizenship associated with home/ holiday or guest/home. Karl takes up an imagined I-refugee position to make his point demonstrating how studies which are designed around dialogical citizens speaking in a public capacity challenge the binaries of populism (Mahendran, 2018; Mahendran, English \& Nieland, 2021).

Karl however reveals a different ambivalence between independence and dependence and the symbolic distance between the two places is foregrounded (in reality they are around $40 \mathrm{~km}$ apart) as well as the two chronotopes. Extract 9 again demonstrate how the lived present, when engaged in homemaking discussions, 
involves projections into the future (see Table 2). Here Karl finds closure and light to the potential for his hometown to overshadow his present by imagining his parents passing away. Whilst $\mathrm{N}$-holm represents the past, he creates a representation of a future where he has achieved his migration to his wife and to Gothenburg.

\section{Discussion}

This article examines how the public's dialogical creation of home potentially diffracts the black/white us/them binaries of populist leaders into a spectrum of positions relating to intergenerational and transglobal dialogues. This proposes that besides the noun of home as site/sense or place vital to "Go-Home/Go-Back" practices, there is a process of home (homemaking, as verb) which involves the public's dynamic relational agency. In our analysis, this centred around intergenerational dialogues which created distinct chronotopes and transglobal dialogues which organized the world in ways beyond racialized nationstate logics. Citizens showed the capacity to widen their horizons and potentially shape their futures in line with the aspirational post-imperial envisioning of Frantz Fanon.

A central finding of the analysis is that home as homemaking involves a developmental process relating to ancestry, birthplace, imagined futures, imagined losses and final resting places. This developmental process drew upon a social representation of how the world was organized which involved key diffracted positions. These can be identified as follows, one world (Mahendran, 2017), a segmented world, a world of nations or transnational cooperation. Beyond this we found in one case a cosmological sense of being beyond this earthly world (see Table 1). Homemaking involving guest/host or home/holiday positioning which may well become important during post-pandemic recovery, particularly as such recovery, is likely to combine austerity policies with increased suspicion towards people who move across borders. The positioning of those designated Other (either by racialized logics or anti-immigration discourse) may well draw upon guest/home and home/holiday discourse to suggest divided loyalties.

Intergenerational dialogue was used by our participants as a form of horizontal anchoring which tethered unfinalized transglobal openings in citizens' dialogical creation of home. Citizens move back and forth between past and future relationships enabling future horizons to be open, and equally to be closed in order to anchor the present (see Table 2). This capacity to reason through a variety of positions represents a methodological challenge to intergroup social cognition studies which reveal hyper-partisanship, conflictual thinking and antagonistic reasoning (Spruyt, et al 2016). Specifically, the challenge then is to design large-scale surveys into populism which have statistical power but enable participants to reveal their multiple positionality. It is important to note that transglobal dialogue occurred across the Migration-Mobility Continuum-it was not confined to migrants.

As outlined earlier in this article, populist leaders are heavily reliant on a threatened present chronotope (Mols \& Jetten, 2014) which draws on a glorious past to project an imagined great future. Can the public's use of the transglobal and past/present/future dialogues decolonize home? Home as built on relational attachment (Fortier, 2001) occurs throughout this analysis.

It is important to note that the analysis starkly foregrounds how EU freedom of movement for those who have white skin is quite distinct from our participants with black and brown skins. Our evidence of contested citizenship raises the question of indexing, 
enduring racialized logics and limits on the capacity to move (Sheller, 2017). Studying the political mobilization of unexamined primordial myths of home and the on-going treatment of black and brown skinned people as out of place, despite holding jus soli or jus sanguinis citizenship is a key challenge for scientists. Particularly those wishing to contribute to movement such as Black Lives Matters and what can be understood as the third wave of decolonization across the globe during post-pandemic recovery and the climate crisis. In the European context, this involves recognition of the extent to which the EU project brings together colonial powers (Bhambra \& Narayan, 2017) and a willingness to move towards a post-imperial consciousness.

In this regard, politicians leading the European Union project need to catch up with the public's multi-positionality on home which appears to go beyond both nation and transnational towards the transglobal irrespective of degree of migration-mobility. This study foregrounds the importance of understanding migration-mobility as occurring along a continuum (Mahendran, 2017; Mahendran, 2018). The multi-positionality we found is perhaps partly as a result of the extent to which the Covid-19 pandemic and the ecological crises are creating psychological worldviews which are in themselves global, a form of pandemicality, as dialogical relational capacity. Progressive political leadership which seeks to understand a spectrum of articulated social representations of home and their related I-positions have the potential to decolonize home. This examination would make it becomes harder for "un-homing" strategies to succeed.

We do not propose to argue that citizens are global citizens or cosmopolitans; rather we find at the level of socio cultural and political psychology, citizens create developmental accounts of home which draw upon a relational agency with distinct past/present/future chronotopes. A key parameter of this analysis is that no direct questions were asked on the home concept within the study. Studies into the psychological dynamics of home-as articulated by citizens and also as mobilized by political actors-could counter xenophobic protectionism of nationalist populist projects and the current limits of European Union's freedom of movement.

Nationalist Populist leaders succeed in un-homing, dislocating and unsettling the demos by explicit and implicit uses of the home concept. This works in two ways: those who are generationally settled fear incomers who will challenge their way of life. Those who have some degree of migration-mobility are made insecure by imagining others are more at home than themselves. The ambition of such political projects is to avoid both groups being coeval, historically located together, to deny and dislocate one, often racialized group, as out of place. Interdisciplinary projects which demonstrate the intergenerational and transglobal continuities involved in homemaking during post-pandemic recovery could potentially support the creation of the necessary counter social representations. To propose that an increasing number of people have "no obvious home" is to simultaneously acknowledge a hegemonic representation of home as fixed to place and disavow it with an alternative representation. It is the conditions of multi-positionality (and indeed the methodological conditions which facilitate their expression amongst participants in scientific studies) which will allow for differing conceptualizations of home. Studies which articulate a diffracted spectrum of positions make possible different ways of living and belonging. This requires the location of home, as an analytical category, at the centre of scientific investigations into citizenship, migration-mobility and belonging.

Data Availability The data that support the findings of this study are available on request from the corresponding author, Dr Kesi Mahendran. The data are not publicly available due to the confidential nature of 
the data, i.e. (restrictions, e.g. their containing information that could compromise the privacy of research participants).

Code Availability The project included the use of NVivo-12; however, coding was not done using the software beyond the initial searches. These searches are available from the corresponding author Dr Kesi Mahendran. The coding are not publicly available due to the confidential nature of the data, i.e. (restrictions, e.g. their containing information that could compromise the privacy of research participants).

\section{References}

Abreu, M. N. (2020). The cultural psychology of white normativity: a draft to the concept of white psyche. Human Arenas, 1-13.

Arendt, H. (1961). Between past and future. New York, NY: Meridian.

Ahmed, S., Castada, C., Fortier, A.-M., \& Sheller, M. (Eds.). (2003). Uprootings/regroundings: questions of home and migration. Oxford: Routledge.

Bakhtin, M. M. (1975/1981). The dialogical imagination: four essays M. Holquist (Ed.). Austin: University of Texas Press. (Original work published 1975).

Bhambra, G. K., \& Narayan, J. (Eds.). (2017). European cosmopolitanism: colonial histories and postcolonial societies. London: Routledge.

Bhatia, S. (2002). Acculturation, dialogical voices and the construction of the diasporicself. Theory \& Psychology, 12, 55-77. https://doi.org/10.1177/0959354302121004.

Bhatia, S., \& Priya, K. R. (2018). Decolonizing culture: Euro-American psychology and the shaping of neoliberal selves in India. Theory \& Psychology, 28(5), 645-668.

Council of the European Union. (2004). Common basic principles for immigrant integration policy in the EU. 14615/04 (Presse 321). Retrieved from https://ec.europa.eu/migrant-integration/librarydoc/ Common-basic-principles-for-immigrant-integration-policy-in-the-eu.

Dewey, J. (1927/1954). The public and its problems. Athens: Swallow Press/Ohio University Press.

Fanon, F. (1961/2001) The Wretched of the Earth, London: Penguin.

Fortier, A.-M. (2001). 'Coming home': queer migrations and multiple evocations of home. European Journal of Cultural Studies, 4(4), 405-424.

Hall, S. (1990). Cultural Identity and Diaspora, in J. In Community Identity \& Difference Culture (Eds.), Rutherford (pp. 222-37). London: Lawrence \& Wishart.

Hall, S. (2017/2018) Familiar stranger: a life between two islands. London: Allen Lane/Penguin.

Hellström, A., \& Nilson, T. (2010). 'We are the good guys' Ideological positioning of the nationalist party Sverigedemokraterna in contemporary Swedish politics. Ethnicities, 10, 55-76. https://doi. org/10.1177/1468796809354214.

Hermans, H. J., \& Dimaggio, G. (2007). Self, identity, and globalization in times of uncertainty: a dialogical analysis. Review of general psychology, 11(1), 31-61.

Kinnvall, C., \& Lindén, J. (2010). Dialogical selves between security and insecurity. Theory \& Psychology, 20(5), 595-619. https://doi.org/10.1177/0959354309360077.

Mahendran, K. (2017). Public narratives on human mobility: Countering technocratic and humanitarian refugee narratives with a "one-world" solidarity narrative. Journal of Community \& Applied Social Psychology, 27(2), 147-157.

Mahendran, K. (2018). From Polarized We/They Public Opinion on European Integration Towards Social Representations of Public Dialogue. Political Psychology, 39(6), 1339-1355.

Mahendran, K. (2021, Forthcoming) Dialogical Citizens, Integration, and the Possibilities of Diffraction in S.J. Cooper-Knock and Duduzile S. Ndlovu (Eds.) Liberating Comparisons, York Tree Publications.

Mahendran, K., English, A., \& Nieland, S. (2021, Forthcoming). Populism vs. the People: How citizen's social representations of home destabilize national populism's territorial vision, Journal of Theoretical Social Psychology.

Marková, I. (2000). Amédée or how to get rid of it: Social representations from a dialogical perspective. Culture \& Psychology, 6, 419-460.

Marková, I. (2003). Dialogicality and social representations: The dynamics of mind. Cambridge: Cambridge University Press.

Marsico, G., \& Tateo, L. (2017). Border, tensegrity and development in dialogue. Integrative Psychological \& Behavioral Science, 51(4), 536-556. https://doi.org/10.1007/s12124-017-9398-2. 
Mitzen, J. (2018). Feeling at home in Europe: migration, ontological security, and the political psychology of EU bordering. Political Psychology, 39, 1373-1387.

Mols, F., \& Jetten, J. (2014). No guts, no glory: How framing the collective past paves the way for antiimmigrant sentiments. International Journal of Intercultural Relations, 43, 74-86.

Moscovici, S. (1984). The phenomenon of social representations. pp. 3-69. In Farr, R.M. \& Moscovici. S., Social Representations (pp 3 - 69). Cambridge: Cambridge University Press.

Mudde, C. (2019). The 2019 EU Elections: moving the center. Journal of Democracy, 30(4), $20-34$.

Murrani, S. (2020). Contingency and plasticity: the dialectical re-construction of the concept of home in forced displacement. Culture \& Psychology, 26(2), 173-186. https://doi.org/10.1177/1354067X19871203.

Nesbitt-Larking, P. (2008). Dissolving the diaspora: dialogical practice in the development of deep multiculturalism. Journal of Community and Applied Social Psychology, 18(4), 351-362.

Obradović, S., Power, S. A., \& Sheehy-Skeffington, J. (2020). Understanding the psychological appeal of populism. Current Opinion in Psychology, 25, 125-131.

Recchie, E., Favell, A., Apaydin, F., Barbulescu, R., Braun, M., Ciornei, I., et al. (2019). Everyday Europe: social transnationalism in an unsettled continent. Bristol: Policy Press.

Rose, N. (2017). Still 'like birds on the wire'? Freedom after neoliberalism, Economy and Society. 46(3-4), 303-323. https://doi.org/10.1080/03085147.2017.1377947.

Savage, M., Cunningham, N., Reimer, D. \& Favell, A. (2019) Cartographies of social transnationalism, in Recchie, E., et al Everyday Europe: Social transnationalism in an unsettled continent, (35 - 59) Bristol: Policy Press.

Sheller, M., \& Urry, J. (2006). The new mobilities paradigm. Environment and Planning A: Economy and Space, 38, 207-226.

Sheller, M. (2017). From spatial turn to mobilities turn. Current Sociology Monograph, 65(4), 623-639.

Simão, L. (2007). Why "Otherness" in the research domain of semiotic-cultural constructivism? In L. M. Simão \& J. Valsiner (Eds.), Otherness in Question: Labyrinths of the Self (pp. 11-36). Charlotte, NC: Information Age Publishing Inc.

Singh, R. (2017). 'I, the people': a deflationary interpretation of populism, Trump and the United States constitution. Economy and Society, 46(1), 20-42.

Spruyt, B., Keppens, G., \& Van Droogenbroeck, F. (2016). Who supports populism and what attracts people to it? Political Research Quarterly, 69, 335-346.

Staerklé, C., \& Green, E. G. T. (2018). Right-wing populism as a social representation: a comparison across four European countries. Journal of Community \& Applied Social Psychology, 28(6), 430-445.

Tateo, L. (2019). 'Atmos-fear': a psycho-semiotic analysis of messages in New York everyday life. Semiotica, 226, 169-184.

Zittoun, T. (2014). Three dimensions of dialogical movement. New Ideas in Psychology, 32(1), 99-106. https://doi.org/10.1016/j.newideapsych.2013.05.006.

Publisher's Note Springer Nature remains neutral with regard to jurisdictional claims in published maps and institutional affiliations. 